BUSTANUL FUQAHA: Jurnal Bidang Hukum Islam

Vol. 1, No. 1 (2020) : Hal. 93-105

Website: https://journal.stiba.ac.id

\title{
STUDI EKSISTENSI HUKUM ISLAM PADA PERATURAN DAERAH DI SULAWESI SELATAN
}

\author{
Ariesman \\ Sekolah Tinggi Ilmu Islam dan Bahasa Arab (STIBA) Makassar \\ Email: ariesman@stiba.ac.id \\ Iskandar \\ Sekolah Tinggi Ilmu Islam dan Bahasa Arab (STIBA) Makassar \\ Email: iskandarkato@stiba.ac.id
}

\begin{abstract}
Keywords :
ABSTRACT

islamic, law, regional Islamic law existed in Indonesia in the 7th century $A D$ or the regulation, south sulawesi first century Hijri. This is in line with the entry and development of Islam in Indonesia, whereas previously Indonesians embraced animism, dynamism and Hindu-Buddhist beliefs which were very far from Islamic values. The development of Islamic Law in Indonesia continues to experience development in all regions in the archipelago, including has spread in South Sulawesi, so that the values or rules of Islam have colored all aspects of community life in South Sulawesi. Based on the results of the literature study, the development of Islamic law in South Sulawesi began since Islam was officially accepted by King Gowa-Tallo on Friday night, September 22, 1605 AD The first king to accept Islam on that day was a king from Tallo named I Malingkaang Daeng Mannyonri, the king then changed his name to Sultan Abdullah Awwalul Islam. In line with the long course of time the development of Islamic law is increasingly showing its existence through the birth of the "Islamic Sharia Enforcement Preparation Committee" (KPPSI) which was inaugurated on April 15, 2001 AD at the al-Markaz al-Islami Mosque in Makassar and various official regulations issued by the provincial, district and village level governments.
\end{abstract}

Kata kunci :

hukum, islam, peraturan daerah, dan sulawesi selatan.

\section{ABSTRAK}

Hukum Islam telah ada di Indonesia pada abad ke-7 Masehi atau abad pertama hijriah. Hal tersebut seiring saat masuknya dan berkembangnya agama Islam di Indonesia, padahal sebelumnya orang Indonesia menganut kepercayaan animisme, dinamisme dan Hindu-Budha yang sangat jauh dari nilai-nilai Islam. Perkembangan Hukum Islam di Indonesia terus mengalami perkembangan di seluruh wilayah di Nusantara, termasuk telah tersebar di Sulawesi Selatan, sehingga nilai-nilai atau aturan Islam telah mewarnai segala sendi kehidupan masyarakat di Sulawesi Selatan. Berdasarkan hasil kajian kepustakaan, perkembangan hukum Islam di Sulawesi Selatan dimulai sejak Islam secara resmi diterima oleh Raja Gowa-Tallo pada Jumat 
malam, tanggal 22 September 1605 M. Raja pertama yang menerima Islam pada hari itu adalah seorang raja dari Tallo bernama I Malingkaang Daeng Mannyonri, raja tersebut kemudian mengubah namanya menjadi Sultan Abdullah Awwalul Islam. Sejalan dengan perjalanan waktu yang panjang pengembangan hukum Islam semakin lama semakin menujukkan eksistensinya melaui lahirnya "Komite Persiapan Penegakan Syariah Islam" (KPPSI) yang diresmikan pada tanggal 15 April 2001 M di Masjid al-Markaz al-Islami Makassar dan berbagai aturan resmi yang di keluarkan oleh pemerintah tingkat provensi, kabupaten, serta desa.

\section{PENDAHULUAN}

Potret sejarah legislasi hukum Islam di Indonesia sebenarnya dapat dibaca mulai dari masuknya Islam ke negeri ini. Secara sosiologis dan kultural, hukum Islam telah menyatu dan menjadi hukum yang hidup. ${ }^{1}$ Semenjak datangnya Islam ke Indonesia pada abad ke-7 $\mathrm{M}$ dengan penyebaran begitu cepat, pada abad ke-13 $\mathrm{M}$ dan ke-14 M Islam mulai dianggap sebagai kekuatan politik dan menggesar adat setempat secara perlahan. Bahkan beberapa abad setelah Islam tersebar di Indonesia, sudah tercatat beberapa kesultanan Islam yang menerapkan hukum Islam secara sah sebagai hukum pemerintahan kesultanan tersebut. Hukum Islam sudah menampakkan eksistensinya dan berlaku secara formal sebagai hukum positif jauh sebelum kedatangan penjajahan Belanda di Indonesia . ${ }^{2}$

Masuknya Islam ke Sulawesi Selatan menurut Ensiklopedi Islam melalui dua tahapan. Pertama, secara tidak resmi melalui jalur perdagangan. Kedua, Islam secara resmi diterima oleh Raja Gowa-Tallo pada malam Jumat 22 September 1605 M yang ditandai dengan kedatangan tiga orang datuk yang berasal dari kota tengah, Minangkabau. Setelah memeluk Islam, raja mengganti namanya menjadi Sultan Abdullah Awwalul Islam, sehingga mulai saat itu penerapan prinsip dan konsep Islam menjadi bagian keseharian masyarakat sulawesi selatan. ${ }^{3}$

Indonesia adalah negara hukum sebagaimana disebutkan dalam landasan Konstitusional Undang-Undang Dasar $1945 .{ }^{4}$ Proses untuk mengubah tata kehidupan masyarakat ke arah yang lebih baik harus terlebih dahulu mampu melaksanakan

${ }^{1}$ Mahsun Fuad, Hukum Islam Indonesia: Dari Nalar Partisipatoris HinggaEmansipatoris, (Yogyakarta: LKIS, 2005), h. 49.

2 Amran Suadi, Mardi Candra, Politik Hukum: Perspektif Hukum Perdata dan Pidana Islam serta Ekonomi Syariah, (Jakarta: Prenadamedia Group: 2016), h. 340.

3 Nelmawarni dan Idawati Djohar, Laporan Penelitian Tiga Tokoh Minangkabau Pembawa Islam ke Sulawesi Selatan, (Padang: Institut Agama Islam Negeri Imam Bonjol Padang, 2013), h. 1.

${ }^{4}$ Lihat Pasal 1 ayat (3) UUD 1945 Hasil Amandemen 2002. 
pembangunan di bidang hukum. ${ }^{5}$ Padahal eksistensi hukum Islam dalam peraturan perundang-undangan Indonesia sudah jelas kepastian hukumnya, juga perjuangan para ulama terdahulu merupakan rangkaian sebuah cita-cita bangsa Indonesia hingga adanya lembaga Peradilan Agama. ${ }^{6}$

Hukum Islam dan politik adalah dua sisi yang tidak bisa dipisahkan dalam suatu masyarakat Islam. Hukum Islam tanpa dukungan politik sulit mengingat dan diterapkan di masyarakat. Politik yang mengabaikan hukum Islam akan mengakibatkan kekacauan dalam masyarakat. Semakin baik hubungan Islam dan politik, semakin besar peluang hukum Islam diaktualisasikan, dan semakin renggang hubungan Islam dan politik, semakin kecil peluang hukum Islam diterapkan. ${ }^{7}$ Ismail Sunny, mengilustrasikan politik hukum sebagai suatu proses penerimaan hukum Islam digambarkan kedudukannya menjadi dua periode, yakni pertama, periode persuasive source di mana setiap orang Islam diyakini mau menerima keberlakuan hukum Islam itu dan kedua, periode authority source dimana setiap orang Islam meyakini bahwa hukum Islam memiliki kekuatan yang harus dilaksanakan. Dengan kata lain, hukum Islam dapat berlaku secara yuridis formal apabila dikodifikasikan dalam perundang-undangan nasional. ${ }^{8}$

Berkaitan dengan hal di atas, tidak dapat dipungkiri bahwa masyarakat Indonesia mayoritas beragama Islam, dan karenanya dapat dipahami apabila ada keinginan dalam penyusunan hukum nasional Indonesia yang sumber hukumnya berdasarkan Al-Quran, As-Sunnah, dan Al-Ijtihad yang menjadi bagian dari peraturan daerah (Perda) masyarakat. ${ }^{9}$ Berdasarkan hal tersebut, penting untuk dibahas mengenai eksistensi hukum Islam di Sulawesi Selatan dalam pembentukan peraturan daerah dan upaya penegakan aturan atau hukum Islam di segala sendi kehidupan masyarakat di Sulawesi Selatan, tentunya dengan mempertimbangkan segala aspek untuk kemaslahatan untuk mewujudkan daerah yang berkah dan sejahtra.

\section{PEMBAHASAN}

\section{Sejarah Hukum Islam di Indonesia}

Hukum Islam baru dikenal di Indonesia setelah agama Islam disebarkan di tanah air Indonesia. Paling tidak, ada dua pendapat mengenai masuknya Islam di Indonesia.

${ }^{5}$ Mura P. Hutagalung, Hukum Islam dalam Era Pembangunan (Jakarta: Penerbit Ind Hill, 1985), h. 9.

6 Jumni Nelli, "Kritik Terhadap Kompilasi Hukum Islam (KHI) Tentang Pasal Sahnya Perkawinan dan Pencatatan Perkawinan," Jurnal Hukum dan HAM, Cet. Ke-1, (Pekanbaru 2012), h. 20-21.

7 Abdul Halim, Peradilan Agama dalam Politik Hukum di Indonesia, (Jakarta: PT RajaGrafindo Persada, 2000), h. xii-xiv.

${ }^{8}$ Amran Suadi, Mardi Candra, Politik Hukum: Perspektif Hukum Perdata dan Pidana Islam serta Ekonomi Syariah, (Jakarta: Prenadamedia Group: 2016), h. 5.

${ }^{9}$ K.N. Sofyan Hasan, Pengantar Hukum Zakat dan Wakaf (Surabaya: Penerbit Al-Ikhlas, 1995), h. 10. 
Pertama, pendapat yang mengatakan bahwa Islam masuk ke Indonesia pada abad ke-13 M. Pendapat ini dikemukakan oleh para sarjana, antara lain N.H. Krom dan Van Den Berg. Kedua, pendapat yang mengatakan bahwa Islam masuk ke Indonesia pada abad ke-7 $\mathrm{M}$ atau abad 1 Hijriyah. Pendapat ini dikemukakan oleh H. Agus Salim, M. Zainal Arifin Abbas, Hamka, Sayed alwi bin Tahir Alhadad, A. Hasyimy, dan Thomas W. Arnold. Menurut kesimpulan "Seminar Masuknya Islam ke Indonesia" di Medan tahun 1963, Islam masuk ke Indonesia sudah semenjak abad pertama Hijriyah atau abad ke-7 M. ${ }^{10}$ Simpulan ini didukung oleh kenyataan dengan adanya makam, yang merupakan tradisi dan ciri khas umat Islam dalam memelihara mayat, yang sebelumnya tidak pernak dikenal dalam tradisi masyarakat Hindu-Budha. ${ }^{11}$

Pada saat Islam datang, secara perlahan-lahan ajaran Islam diterima oleh masyarakat dan menggeser keyakinan animisme, dinamisme serta ajaran-ajaran agama Hindu-Budha yang telah ada dan dianut masyarakan Indonesia sebelumnya. Ajaran Islam juga secara berangsur-angsur diterapkan dan dilaksanakan dalam kehidupan sehari-hari. Penerapan hukum Islam ini bukan hanya pada pelaksanaan ibadah-ibadah tertentu melainkan juga diterapkan pula dalam masalah-masalah muamalat, pernikahan (munakahat) dan hukum / uqubat (jinayah/hudud).

Sebelum belanda menerapkan politik hukumnya di Indonesia, hukum Islam merupakan hukum yang berdiri sendiri dan mempunyai kedudukan yang kuat, baik pada tataran masyarakat maupun dalam perundang-undangan negara. Penerimaan dan penerapan hukum Islam ini dapat dilihat pada masa-masa awal kerajaan Islam. Pada masa kesultanan Islam, hukum Islam sudah diberlakukan secara resmi sebagai hukum negara (hukum positif). Kerajaan-kerajaan Islam yang pernah berdiri di Indonesia melaksanakan hukum Islam dalam wilayah kekuasaannya masing-masing, seperti Kerajaan Islam Samudera Pasai yang berdiri di Aceh pada akhir abad ke-13, dilanjutkan dengan berdirinya kerajaan-kerajaan Islam lainnya, seperti Demak, Jepara, Tuban, Gresik, Ngampel dan Banten. Di bagian timur Indonesia berdiri pula Kerajaan Tidore dan Makassar. Dan selanjutnya pada pertengahan abad ke-16, berdiri sebuah dinasti yakni Kerajaan Mataram. ${ }^{12}$

\section{Kerajaan Islam dan Penerapan Hukum}

Beberapa aspek politik hukum Islam yang telah berkembang pada beberapa kerajaan Islam di Indonesia diantaranya adalah sebagai berikut:

\section{Kerajaan Samudera Pasai (1267-1521 M)}

${ }^{10}$ Samsul Munir Amin, Sejarah Peradaban Islam,(Jakarta: AMZAH, 2009), h.302-303.

11 Oyo Sunaryo Mukhlas, Perkembangan Peradilan Islam, (Bogor: Ghalia Indonesia,2011), h. 119

${ }^{12}$ Aliddin Koto, Sejarah Peradilan Islam, (Jakarta: PT RajaGrafindo Persada,2011),h. 197-198. 
Kerajaan Islam Pasai yang berdiri di Aceh Utara pada akhir abad ke-13 M, merupakan kerajan Islam pertama di Indonesia, dengan Malik al-Saleh sebagai sultan pertama, yang kemudian diikuti dengan berdirinya kerajaan-kerajaan Islam lainnya. Kemunculan sistem kekuasaan pada akhir abad ke 13 M di Samudera Pasai, yaitu bentuk kesultanan, telah merubah secara menyeluruh sistem politik yang telah telah ada, maka sejak saat itu Islam memainkan peran penting dalam menata sistem kehidupan masyarakat yang lebih baik. ${ }^{13}$

Seperti yang telah ditulis oleh Ibn Batutah, seorang pelancong Maroko, ketika mengisahkan perjalanannya di Samudera Pasai, ia juga menulis perihal praktik hukum Islam di Samudera Pasai, bahwa mazhab hukum Islam yang diikuti oleh sultan dan penduduk di Samudera Pasai adalah mazhab Syafi'i. Di Samudera Pasai juga diberlakukan lembaga-lembaga keagaamaan seperti qadhi dan mufti. Pelaksanaan jihad, jizyah, dan pemisahan wilayah Islam dan bukan-Islam di Kesultanan Samudera Pasai berkait dengan pemikiran dan aturan hukum Islam.$^{14}$

\section{Kerajaan Aceh Darussalam (1496-1903 M)}

Salah satu nama kerajaan Islam terbesar di Indonesia adalah kerajaan Aceh Darussalam. Kerajaan ini berdiri pada tahun $1511 \mathrm{M}$ bersamaan dengan jatuhnya Malaka ke tangan Portugis. Sultan Ali Mughiyah Syah yang terkenal dengan sebutan Sultan Ibrahim menjadi penguasa pertama (1514-1528) sekaligus sebagai pendiri kerajaan Aceh Darussalam. ${ }^{15}$

Sultan Iskandar Muda, sultan yang telah menghantarkan Aceh Darussalam ke masa gemilangnya, ternyata sangat ketat dalam menerapkan hukum Islam. Sesuai dengan konstitusi kerajaan Aceh Darussalam "Qanun Meukuta Alam” yang bersumber dari AlQuran dan Hadis, Sultan Iskandar Muda menerapkan hukuman mati, seperti hukuman rajam bagi putranya yang bernama Meurah Pupok karena terbukti berzina dengan istri seorang perwira kerajaan. Sultan Iskandar Muda juga mengeluarkan kebijakan mengharamkan riba dalam wilayah kekuasaannya. ${ }^{16}$

Di kerajaan Aceh Darussalam, peran keagamaan dipimpin oleh seorang ulama yang disebut syaikhul Islam. Dialah yang menjadi patron berbagai kebijakan pemerintahan berkaitan dengan agama. Pada masa syaikhul Islam dipegang oleh Nuruddin ar-Raniry (1637-1641), ia mengarang beberapa kitab yang kemudian menjadi pegangan para hakim di seluruh wilayah kekuasaan Aceh dalam memutuskan perkara. Hal yang sama juga

13 Ayang Utriza Yakin, "Islamisasi dan Syariatisasi Samudera-Pasai Abad Ke-14 Masehi”, ISLAMICA, Volume 9, No. 1, September 2014, h. 278.

14 Ayang Utriza Yakin, "Islamisasi dan Syariatisasi Samudera-Pasai Abad Ke-14 Masehi”, ISLAMICA, Volume 9, No. 1, September 2014, h. 281-288.

${ }^{15}$ M. Yahya Harun, Kerajaan Islam Nusantara Abad XVI dan Abad XVII, (Yogyakarta: Karunia Kalam Sejahtera, 1995), h. 11-12.

${ }^{16}$ Amran Suadi, Mardi Candra, Politik Hukum: Perspektif Hukum Perdata dan Pidana Islam serta Ekonomi Syariah, (Jakarta: Prenadamedia Group: 2016),h. 341. 
dilakukan pada masa pemerintahan Sultanah Safiatuddin (1641-1675) dengan syaikhul Islam Abdurrauf Syiah Kuala (1642-1693). ${ }^{17}$

Pelaksanaan hukum Islam di kerajaan Aceh ini menyatu dengan peradilan negara dan dilakukan secara bertingkat mulai dari kampung yang dipimpin oleh Keucik, untuk perkara-perkara ringan saja. Sedangkan perkara-perkara berat diselesaikan oleh Balai Hukum Muhkim. Peradilan tingkat kedua yang merupakan peradilan banding adalah Oeloebalang. Jika keputusan Oeloebalang tidak memuaskan, dapat dimintakan banding di peradilan ketiga yaitu Panglima Sagi. Keputusan Panglima Sagi bisa dimintakan banding kepada sultan pengadilan tertinggi. Pelaksanaannya dilakukan oleh Mahkamah Agung yang terdiri dari Malikul Adil, Orang Kaya, Sri Paduka Tuan, Orang Kaya Raja Bandahara, dan Faqih (Ulama). ${ }^{18}$

\section{Kerajaan Makassar-Sulawesi Selatan (1591-1669 M)}

Kerajaan Makassar sering disebut juga Kerajaan Gowa dan Tallo. Kedua kerajaan itu telah bekerjasama dan terjalin hubungan baik, sehingga banyak orang luar hanya mengenal sebagai kerajaan Makassar saja. ${ }^{19}$ Masuknya Islam ke Sulawesi Selatan menurut Ensiklopedi Islam melalui dua tahapan. Pertama, secara tidak resmi melalui jalur perdagangan. Banyak pedagang asal Sulawesi berdagang keluar pulau dan bertemu dengan saudagar muslim, begitupun sebaliknya. Kedua, Islam secara resmi diterima oleh Raja Gowa-Tallo pada malam Jumat 22 September 1605 M yang ditandai dengan kedatangan tiga orang datuk yang berasal dari kota tengah, Minangkabau. Raja pertama yang menerima Islam pada hari itu juga ialah raja Tallo yang bernama I Malingkaang Daeng Mannyonri. Disamping sebagai raja, Baginda Tallo merangkap sebagai Tumabbicara Butta atau Mangkubumi Kerajaan Gowa. Setelah memeluk Islam, raja mengganti namanya menjadi Sultan Abdullah Awwalul Islam . Menyusul kemudian raja Gowa XIV I Mangngerengi Daeng Manrabbia memeluk Islam dan berganti nama menjadi Sultan Alauddin. ${ }^{20}$

Dengan datangnya Islam yang disetujui oleh kedua kerajaan tersebut kemudian keduanya menjadi kerajaan terkuat. Hal tersebut dikuatkan kembali dengan terjadinya konversi ke dalam Islam secara besar-besaran yang ditandai dengan keluarnya dekrit oleh Sultan Alauddin pada 9 November 1607 M. dekrit tersebut berbunyi: "Kerajaan

${ }^{17}$ Amran Suadi, Mardi Candra, Politik Hukum: Perspektif Hukum Perdata dan Pidana Islam serta Ekonomi Syariah, (Jakarta: Prenadamedia Group: 2016),h. 343.

${ }^{18}$ Aliddin Koto, Sejarah Peradilan Islam, (Jakarta: PT Raja Grafindo Persada, 2011), h. 204.

${ }^{19}$ M. Yahya Harun, Kerajaan Islam Nusantara Abad XVI dan Abad XVII, (Yogyakarta: Karunia Kalam Sejahtera, 1995), h. 65.

20 Nelmawarni dan Idawati Djohar, Laporan Penelitian Tiga Tokoh Minangkabau Pembawa Islam ke Sulawesi Selatan, (Padang: Institut Agama Islam Negeri Imam Bonjol Padang, 2013), h. 1. 
Gowa-Tallo menjadikan Islam sebagai agama kerajaan dan seluruh rakyat yang bernaung dibawah kerajaan harus menerima Islam sebagai agamanya" ${ }^{21}$

Setelah menjadi kerajaan Islam, raja Gowa menempatkan Parewa Syara' (Pejabat Syari'at/Pengadilan tingkat II) yang berkedudukan sama dengan Parewa Adek (Pejabat Adek) yang sudah ada sebelum datangnya Islam. Parewa Syara' dipimpin oleh kali (Qadhi) yaitu pejabat tinggi dalam syariat Islam yang berkedudukan dipusat kerajaan (Pengadilan tingkat III). Di masing-masing Paleli diangkat pejabat bawahan yang disebut Imam serta dibantu oleh seorang Khatib dan seorang Bilal (Pengadilan Tingkat I). Para qhadi dan pejabat urusan tersebut diberikan gaji yang diambilkan dari zakat fitrah, zakat harta, sedekah Idul Fitri dan Idul Adha, kendurui kerajaan, penyelenggaraan mayat dan penyelenggaraan pernikahan. Hal ini terjadi pada saat pemerintah raja Gowa XV (1637-1653) ketika Malikus Said berkuasa. Sebelumnya raja Gowa sendiri yang menjadi hakim agama Islam.$^{22}$

\section{Hukum Islam di Sulawesi Selatan}

Bersamaan dengan bergulirnya era reformasi, masyarakat Sulawesi Selatan telah menemukkan kebebasannya untuk berekspresi setelah kurang lebih tiga dasawarsa terbungkam oleh Orde Baru. Hasil kongres umat Islam Sulawesi Selatan tanggal 19-21 Oktober 2000 yang didukung oleh sejumlah zuamah, ulama, agniya, umara, dan ulul $a l b a b$ dari berbagai organisasi massa, pendidikan/pesantren, sosial serta perguruan tinggi menyepakati dan melahirkan institusi perjuangan yang dikenal "Komite Persiapan Penegakan Syari'at Islam" (KPPSI) yang diresmikan pada tanggal 15 April 2001 di Masjid al-Markaz al-Islami Makassar beriringan dengan dikeluarkannya pernyataan bersama yang dikenal dengan nama 'Deklarasi Muharram' isinya adalah desakan kepada lembaga eksekutif dan legislatif untuk memproses pemberlakuan Syari'at Islam di Sulawesi Selatan sesuai mekanisme konstitusi yang berlaku yang melahirkan rekomendasi DPRD Provinsi Sulawesi Selatan tertanggal 23 April 2001. Kesimpulannya bahwa target yang diperjuangkan KPPSI adalah lahirnya UU Otonomi Khusus sebagai payung, karena dengan wadah tersebut penerapan Syari'at Islam di Sulawesi Selatan dapat diwujudkan.

Kewenangan Otonomi Khusus yang dimintakan itu meliputi: 1) penyelanggaraan kehidupan beragama. 2) penyelanggaraan kehidupan adat istiadat. 3) penyelenggaraan bidang pendidikan. 4) penyelenggaraan bidang ekonomi dan perdagangan. 5) penyelenggaraan mahkamah syariat. 6) peran dan kedudukan ulama dalam pemerintahan. ${ }^{23}$ Namun dalam upaya tersebut, tidak berarti menafikan pendekatan non struktural (kultural) yang lebih menekankan pada penyadaran individu dalam pelaksanaan syariat Islam secara button up yang dipandang lebih adaptif dan persuasif.

${ }^{21}$ Nidia Zuraya, "Masuknya Islam di Pulau Sulawesi”, Republika, B6 (Januari 2011). 2015, h. 316

${ }^{22}$ Ahmad R, "Peradilan Agama di Indonesia", Yudisia, Volume. 6, No. 2, Desember

${ }^{23}$ Endang Turmudzi dkk, Pengaruh Modernitas terhadap Sikap Keberagaman Penerapan dan Diskursus Politik Syari'at Islam (Jakarta: Puslitbang, 2003), h. 60. 
Adapun konsep model penerapan syariat Islam yang diperjuangkan KPPSI berdasarkan tiga asas yaitu;

1. Asas tidak memberatkan (QS. al-Haj ayat 78).

2. Asas tidak memperbanyak beban (QS. al-Baqarah ayat 286).

3. Asas Attadarruj (bertahap). ${ }^{24}$

Dari ketiga asas itulah KPPSI memperjuangkan programnya ${ }^{25}$ yang kini gencar melakukan sosialisasi secara intensif dan menyeluruh tentang pengertian Syari'at Islam yang memang disadari masih banyak lapisan masyarakat muslim yang tidak memiliki pemahaman yang benar dan utuh tentang Syari'at Islam.

KPPSI aktif mendorong menjadikan UU No. 22 tahun 1999 tentang pemerintah daerah dan UU No. 25 tahun 1999 tentang pertimbangan keuangan antara pemerintah pusat dan daerah, yang terkenal sebagai UU Otonomi Daerah ${ }^{26}$ untuk kepentingan penegakan Syari'at Islam. Hasilnya tercatat beberapa daerah kabupaten seperti: Bulukumba, Maros, Pangkep, dan Enrekang telah mengeluarkan peraturan daerah (Perda) tentang pengelolaan zakat profesi, infak, dan sedekah, pandai baca al-Qur'an bagi siswa dan calon pengantin, larangan, pengawasan, penertiban, peredaran dan penjualan minuman beralkohol. Ketiga Perda tersebut di atas, telah diberlakukan (1) di daerah Bulukumba (Perda No. 63 tahun 2002 tentang larangan, pengawasan, penertiban, peredaran, dan penjualan minuman beralkohol. Perda No. 02 tahun 2003 tentang pengelolaan zakat profesi, infak dan sedekah. Perda No. 06 tahun 2003 tentang pandai baca al-Qur'an bagi siswa dan calon pengantin. Perda No. 05 tahun 2003 tentang berpakaian muslim dan muslimah. (2) Daerah Kabupaten Maros (Perda No. 09 tahun 2001, tentang larangan pengedaran, memproduksi, mengkonsumsi, minuman keras

24 Dakkwa dan Jihad Komite Persiapan Penegakan Syari'at Islam (KPPSI) Sulsel otonomi khusus sulsel untuk tegaknya Syari'at Islam 2004, h. 11.

25 Program perjuangan KPPSI meliputi 1. Bidang Politik antara lain dinyatakan pembangunan kekuatan umat untuk bersatu padu dalam upaya memperjaungkan tegaknya Syari'at Islam di sulsel secara konstitusional, menurut DPR RI lewat DPRD sulsel untuk segera menerbitkan UU otonomi khusus pelaksanaan Syari'at Islam di sulsel 2. Bidang hukum dan perundang-undangan berdasarkan Syari'at Islam yang menjamin keadilan dan menjadi rahmat bagi seluruh umat manusia, membangun dan meningkatkan kesadaran umat untuk berpegang teguh pada aturan-aturan hukum dan perundang-undangan berdasarkan Syari'at Islam kemudian menasionalisasikannya. Bidang ekonomi perdagangan; merumuskan antara perekonomian dan perdagangan berdasarkan Syari'at Islam melakukan gerakan penyelamatan ekonomi umat. 4. Bidang pendidikan antara lain; merumuskan sistem pendidikan Islam yang menjaga umat dari pola pikir sekularisme dan materialisme yang sangat mengancam akidah umat, dan menjadikan pesantren sebagai basis utama pendidikan Islam. 5. Bidang sosial budaya, antara lain; mengusahakan agar masyarakat tidak terpengaruh terhadap budaya-budaya yang bertentangan dengan ajaran Islam. Menuntut pemerintah menutup tempat usaha yang merusak kehidupan masyarakat dan bertentangan dengan ajaran Islam. Ikhtisar Menuju Darussalam Perjaungan Menuju Syari'at Islam Sulsel. Cet. I. (Jakarta:KPPSI Pustaka al-Raihan, 2005), h. 10.

h. 16 .

${ }^{26}$ Rifyal Ka'bah, Penegakan Syari'at Islam di Indonesia (Jakarta: Khaerul Bayan, 2004), 
beralkohol, narkotika dan psikotropika. Perda No. 15 tahun 2005, tentang gerakan buta aksara, dan pandai baca al-Qur'an bagi siswa, PNS, caleg, dan calon pengantin, dua daerah lainnya yang disebutkan di atas bervariasi dalam merancang dan memberlakukan Perda-Perda sejenis di daerahnya, tetapi yang pasti keempat daerah kabupaten yang tersebut di atas nuansa kehidupan Islami sangat nampak dan terasa dampak positifnya bagi peningkatan kesejahteraan dan ketentraman dengan berlakunya Perda-Perda tersebut. $^{27}$

Dalam disertasi Hamdan Juhannis, terkesan KPPSI disamakan perjuangannya dengan Darul Islam (DI) yang pernah ada di Sulawesi Selatan (1953-1963), dalam hal kesamaan "Spirit Islam Formalis". ${ }^{28}$ Akan tetapi beda latar belakangnya, dasar dan tujuan perjuangannya. DI memperjuangkan berdirinya negara Islam di Indonesia melalui perjuangan bersenjata dengan cara kekerasan, sedangkan KPPSI memperjuangkan penerapan Syari'at Islam khusus di daerah Sulawesi Selatan. Dengan tuntutan pemberian "Otonomi Khusus., seperti halnya diberikan kepada Daerah Istimewa Aceh, melalui peerjuangan konstitusional-demokratis dan tetap komitmen pada NKRI. Hal tersebut sangat logis dan wajar karena didukung oleh masyarakat dan pemerintah daerahnya. Secara yuridis formal, pengaturan syariat Islam di Aceh didasarkan pada Undang-Undang Nomor 44 Tahun 1999 Tentang Penyelenggaraan Keistimewaan Propinsi Daerah Istimewa Aceh dan Undang-Undang Nomor 11 Tahun 2006 tentang Pemerintah Aceh. ${ }^{29}$ Kedua Undang-Undang ini menjadi dasar kuat bagi Aceh untuk menjalankan syariat Islam. Hal ini menandakan syariat Islam adalah bagian dari kebijakan Negara yang di berlakukan di Aceh. Oleh karena itu, dalam konteks pelaksanaannya pun tidak terlepas dari tanggung jawab negara.

Penerapan hukum Islam terus berkembang dan berlangsung di Sulawesi Selatan di antaranya melalui surat edaran :

1. Sebagai tindak lanjut surat Komisi E DPRD Sulsel Nomor: 64/Ko.E/DPRD/X/2016, perihal risalah RDP Komisi E DPRD Prov. Sulawesi Selatan sehubungan dengan Fatwa MUI Nomor 19 Tahun 1997 tentang Nikah Mut'ah, Rekomendasi Rakernas MUI 2014 Nomor 6 tentang Meningkatkan Kewaspadaan Terhadap Penyimpangan Syi'ah, dan Keputusan Komisi A Ijtima' Ulama Komisi Fatwa Se-Indonesia ke V Tahun 2015 tentang Radikalisme Agama, maka sehubungan dengan hal tersebut dihimbau kepada Saudara terhadap hal-hal sebagai berikut: a) Melakukan pengawasan dan kajian-kajian yang melibatkan Kementerian Agama, MUI serta pihak-pihak terkait tentang ajaran Syi'ah yang meresahkan masyarakat; b) Memantau perkembangan, situasi dan kondisi penyebaran ajaran Syi'ah dan

${ }^{27}$ Himpunan Kebijaksanaan Pemda Bulukumba, 2004.

${ }^{28}$ Hamdan Juhannis, The Struggle for Formalis Islam in South Sulawesi fro Darul Islam to KPPSI (Disertasi) Australia: Faculty of Asian Studies, 2006, h. 315.

${ }^{29}$ Syariat Islam di Aceh pernah juga diatur dalam Undang-Undang Nomor 18 Tahun 2001 tentang Otonomi Khusus bagi Propinsi Daerah Istimewa Aceh sebagai Propinsi Nanggroe Aceh Darussalam. Namun, Undang-Undang ini dinyatakan tidak berlaku lagi dan dengan UndangUndang Nomor 11 Tahun 2006. 
mengidentifikasi ormas-ormas yang membawa paham Syi'ah; c) Kanwil Kementerian Agama, Majelis Ulama Sulawesi Selatan dan Para Ormas Islam memberikan pembekalan kepada dai-dai untuk mengantisipasi terkait berkembangnya ajaran Syi'ah; d) Komponen Masayrakat dapat melakukan pembinaan dan pengawasan dengan tidak melakukan kekerasan.

2. Dinas Pendidikan (Disdik) Kota Makassar, Ismunandar sebagai Kepala Dinas Pendidikan Kota Makassar, melarang para siswa mulai tingkat SD, SMP, dan MTs, merayakan Valentine Day diperingati pada 14 Februari, karena cenderung mengarah ke hal-hal negatif yang tidak sesuai dengan norma agama dan budaya. Imbauan dibuat dalam bentuk surat edaran, kepada pihak sekolah untuk melarang kegiatan siswanya dalam bentuk apapun saat hari Valentine Day.

3. Penjabat Sekretaris Daerah Provinsi Sulsel, Drs. H. Tautoto Tana Ranggina, M.Si, membuat gebrakan tiga hari setelah dilantik menjadi Penjabat (Pj) Sekretaris Daerah. Tautoto, membuat surat edaran yang berisi himbauan shalat berjamaah di masjid kepada Aparatur Sipil Negara (ASN) jika adzan berkumandang.

4. Surat Edaran bernomor 120/6759/Wagub yang ditandatangani Wakil Gubernur Sulsel Andi Sudirman Sulaiman,

Memperhatikan fenomena bencana alam yang banyak terjadi akhir-akhir ini, dan menyikapi desakan/masukan beberapa kelompok masyarakat khususnya muslim dalam menilai perilaku maksiat, bentuk budaya kesyirikan, asusila dan lainnya, sebagai salah satu faktor Sang Pencipta Allah Subhana Wa ta'ala memberi cobaan ataupun peringatan yang sifatnya bukan hanya berdampak pada perilaku, tapi juga masyarakat umum lainnya dalam perspektif tinjauan dan keyakinan agama. Sebagai upaya responsif pemerintah dalam menyerap aspirasi serta menjaga kerukunan umat beragama, Maka kami selaku Pemerintah Provinsi Sulawesi Selatan menyampaikan Himbauan sebagai berikut:

a. Setiap kegiatan Propinsi/Kabupaten/Kota untuk selalu memperhatikan agenda atau kegiatan yang dilaksanakan agar sesuai dengan norma agama dan budaya masyarakat setempat.

b. Melakukan koordinasi sesuai urgensi dengan lembaga agama dalam hal ini majelis-majelis agama setempat untuk meminta pandangan dan nasehat setiap kegiatan baik seni, budaya maupun kegiatan lainnya di muka umum.

c. Melakukan kegiatan tradisional yang kreatif tanpa mengeyampingkan aturan budaya dan agama. Serta tetap memperlihatkan karakter sebagai orang Sulawesi Selatan yang religius dan berbudaya.

d. Sebagai insan yang beragama, segenap warga masyarakat dan pemerintah senantiasa berdoa kepada Allah Yang Maha Kuasa agar mendapatkan perlindungan, dan juga kepada warga yang tertimpa bencana alam Serta memberi bantuan kepada mereka sesuai kebutuhan.

5. Wakil Gubernur Andi Sudirman Sulaiman mengeluarkan surat edaran tentang implementasi aturan penegasan pelaksanaan kedisiplinan Aparatur Sipil Negara (ASN) lingkup Pemerintahan Provinsi khususnya larangan merokok di area bebas asap rokok di Kantor Gubernur. Sebagaimana diatur dalam PP 53/2010 tentang 
Disiplin Pegawai Negeri Sipil (PNS) dan Peraturan Daerah (Perda) Nomor 1 Tahun 2015 tentang Kawasan Tanpa Rokok, para pelanggar akan dipidana selama tiga bulan dan dikenakan denda 1 juta rupiah.

6. Surat Edaran Gubernur Sulsel imbau masyarakat tidak pesta tahun baru 2019 sebagai wujud simpati terhadap bencana tsunami di Banten dan Lampung. Surat Edaran tertanggal 26 Desember 2018 yang ditandatangani Wakil Gubernur Sulsel Andi Sudirman Sulaiman.

\section{KESIMPULAN}

1. Hukum Islam telah ada di Indonesia pada abad ke 7 Masehi atau abad pertama Hijriah hal itu bersamaan dengan masuknya Islam di Indonesia, masyarakat Indonesia yang sebelumnya menganut kepercayaan animisme, dinamisme dan ajaran Hindu-Budha. Hal ini bukti bahwa, Islam masuk secara jalur damai, dengan akhlak yang mulia dan ajaran yang sesuai dengan fitrah manusia, sehingga ajaran islam dengan mudah di terima oleh masyarakat.

Kehidupan masyarakat Indonesia telah mulai beralih dengan mengamalkan konsep hidup secara Islami baik pada pribadi, keluarga dan kehidupan bermasyarakat, bahkan sudah menjadi peraturan daerah (Perda) dalam menyelesaikan masalah yang ada. Demikianlah kesadaran, keyakinan mayarakat bahwa dengan aturan Islam segala persoalan akan bisa diselesaikan dengan baik bahkan akan menurunkan berkah dan rahmat dari Allah.

2. Mayoritas raja-raja atau penguasa di suatu wilayah dengan mudahnya masuk ke dalam Islam bahkan meraka dengan sukarela dan merasa bangga gelar-gelar rajaraja atau kebangsawanan di ganti dengan istilah sultan, bahkan undang-undang dalam sistem yang telah mereka terapkan yang menjadi dasarnya adalah al-quran dan hadis.

Islam adalah ajaran yang logis dan paripurna mengatur segala aspek kehidupan, serta akan mengantarkan kepada jalan kebaikan di dunia dan akhirat, sehingga hal yang wajar ketika raja disetiap wilayah di Indonesia ketika diajak untuk memeluk Islam mereka langsung menerima waluapun sebagian diawali dengan diskusi / dialog.

3. Perkembangan hukum Islam di Sulawesi Selatan dimulai sejak Islam secara resmi diterima oleh Raja Gowa-Tallo, bahkan dikeluarkan dekrit oleh Sultan Alauddin pada 9 November 1607 M. dekrit tersebut berbunyi: "Kerajaan Gowa-Tallo menjadikan Islam sebagai agama kerajaan dan seluruh rakyat yang bernaung dibawah kerajaan harus menerima Islam sebagai agamanya."

Kesadaran dan keyakinan kuat dari sultan Alauddin untuk mengajak masyarakat Sulawesi Selatan atau daerah dibawah kerajaan Gowa-Tallo menggambarkan bahwa ajaran Islam adalah ajaran yang benar dan satu-satunya jalan keselamatan dan kebahagiaan masyarakat.

4. Upaya penerapan syariat Islam di Sulawesi Selatan semakin berkembang dan dikuatkan dengan lahirnya "Komite Persiapan Penegakan Syari'at Islam" (KPPSI). 
Hasilnya tercatat beberapa daerah kabupaten seperti; Bulukumba, Maros, Pangkep, dan Enrekang telah mengeluarkan peraturan daerah (Perda) yng mendukung penerapan syariah Islam.

5. Pada perjalanannya hukum Islam di Sulawesi Selatan terus mengalami banyak kemajuan termasuk keluarnya beberapa surat edaran pemerintah provinsi maupun kota bahkan desa berapa hal yang berkaitan tentang pelarangan untuk melakukan kegiatan ritual kesyirikan, larangan tumbuh dan berkembang aliran syiah, larangan untuk mengikuti kegiatan valentine day dan tahun baru, bahkan instruksi kepada Aparatur Sipil Negara (ASN) untuk melaksanakan salat berjamaah di masjid saat adzan dikumandangkan.

6. Prinsip aturan Islam sudah saat menjadi solusi dari berbagai masalah yang ada yang di masyarakat Sulawesi Selatan dengan kesempurnaan ajarannya dan metode dalam penyelesaiannya terbaik, tapi tentu tetap sejalan dengan UUD, Pancasila dan keutuhan NKRI.

\section{DAFTAR PUSTAKA}

Ahmad R, "Peradilan Agama di Indonesia”, Yudisia, Volume. 6, No. 2, Desember 2015.

Amin, Samsul Munir, Sejarah Peradaban Islam, Jakarta: AMZAH, 2009.

Fuad, Mahsun, Hukum Islam Indonesia: Dari Nalar Partisipatoris Hingga Emansipatoris, Yogyakarta: LKIS, 2005.

Halim, Abdul, Peradilan Agama dalam Politik Hukum di Indonesia, Jakarta: PT RajaGrafindo Persada, 2000.

Harun, M. Yahya, Kerajaan Islam Nusantara Abad XVI dan Abad XVII, Yogyakarta: Karunia Kalam Sejahtera, 1995.

Hasan, K.N. Sofyan. Pengantar Hukum Zakat dan Wakaf. Surabaya: Penerbit Al-Ikhlas, 1995.

Hutagalung, Mura P. Hukum Islam dalam Era Pembangunan. Jakarta: Ind Hill, 1985.

Juhanis, Hamdan. The Struggle for Formalis Islam in South Sulawesi from Darl Islam to KPPSI (Disertasi) Australia: Faculty of Asian Studies, 2006.

Ka'bah, Rifyal. Penegakan Syari'at Islam di Indonesia. Jakarta: Kharul Bayan, 2004.

Koto, Aliddin, Sejarah Peradilan Islam, Jakarta: PT RajaGrafindo Persada, 2011.

Mukhlas, Oyo Sunaryo, Perkembangan Peradilan Islam, Bogor: Ghalia Indonesia, 2011. 
BUSTANUL FUQAHA: Jurnal Bidang Hukum Islam

Vol. 1, No. 1 (2020) : Hal. 93-105

Website: https://journal.stiba.ac.id

Nelli, Jumni. Kritik Terhadap Kompilasi Hukum Islam (KHI) Tentang Pasal Sahnya Perkawinan dan Pencatatan Perkawinan. Jurnal Hukum dan HAM, Cet. 1, (Pekanbaru, 2012)

Nelmawarni dan Idawati Djohar, Laporan Penelitian Tiga Tokoh Minangkabau Pembawa Islam ke Sulawesi Selatan, Padang: Institut Agama Islam Negeri Imam Bonjol Padang, 2013.

Suadi, Amran dan Mardi Candra, Politik Hukum: Perspektif Hukum Perdata dan Pidana Islam serta Ekonomi Syariah, Jakarta: Prenadamedia Group: 2016.

Turmudzi, Endang. Dkk. Pengaruh Modernitas terhadap Siakp Keberagaman Penerapan dan Diskursus Politik Syati'at Islam. Jakarta: Puslitbang, 2003.

Yakin, Ayang Utriza, "Islam isasi dan Syariatisasi Samudera-Pasai Abad Ke-14 Masehi", ISLAM ICA, Volume 9, No. 1, September 2014. 